\title{
An Investigation of Forcibly Migrated Syrian Refugee Students at Turkish Public Schools
}

\author{
Rasim Tösten $^{1}$, Mustafa Toprak ${ }^{2, *}$, M. Selman Kayan ${ }^{3}$ \\ ${ }^{1}$ Department of Physical Education and Sports Education, Siirt University, Turkey \\ ${ }^{2}$ Graduate School of Education, American University in Cairo, Egypt \\ ${ }^{3}$ Gaziantep National Ministry of Education, Turkey
}

Copyright $\mathrm{O} 2017$ by authors, all rights reserved. Authors agree that this article remains permanently open access under the terms of the Creative Commons Attribution License 4.0 International License

\begin{abstract}
This study is a descriptive phenomenological research that aims to reveal Syrian refugee children' experiences within formal public schools in Turkey. The data was collected through semi-structured interviews from 28 teachers who teach these refugee Syrian students. Results show that the students are under the effect of post-traumatic stress disorders, they have problems understanding and communicating the content in class, there are issues stemming from overcrowded classes, teachers have not been involved in decision-making processes regarding these students, there does not seem to be an reliable effort to increase teachers' capacities to better deal with these students, nor are they effectively informed about refugee students. The study also presents discussion related to integration of refugee students into mainstream classes, lack of an effective system to address issues, and some suggestions for policy making in the case of refugee students.
\end{abstract}

Keywords Refugee Education, Integration of Refugee Children, Syrian Students, Teachers' Participation

\section{Introduction}

Migration concept can be defined as the relocation of individuals during a certain period of time [1-4]. It is "the movement of a person or a group of persons, either across an international border, or within a state" [5], or "departure, mobilization, hegira or immigration of an individual or communities from a one place to another because of economic, social or political reasons" [6]. People's relocation from one place to another has both a social and geographical dimension [7]. Also, population, political and economic problems, disruptions in environmental conditions, educational inadequacies, and wars are among many reasons behind migration [8].
Migration phenomenon that has a history as old as that of humanity has a multi-dimensional and influential value and is closely related to a society's social, cultural, economic, political, educational, and psychological structure $[1,7,9,10]$. Political factors such as poverty, social changes, conflicts and persecution, and all other factors have led to waves of migration and have made migration a focal point in human development [11].

Literature on migration suggests classifications such as internal/external migration, and forced migration/voluntary migration. While internal migration can be defined as mobilization of individuals for only a certain period of time at their free will to a place outside their original location [2]; [12], external migration is known as population movements to a different country in order to stay, work or reside [13]. Looking at the concept from an individual's free will perspective, migration is classified into two categories; voluntary and forced migration. From this point of view, voluntary migration is relocation of people from one city or region to another based on their free will and certain expectations [14,15]. Forced migration, on the other hand, without making any direct reference to a single reason or act, can result from desires to escape from systematic persecutions, natural life-threatening disasters or random/casual factors $[16,17]$. Based on these classifications, Syrian people's migration into Turkey can be considered an external forced migration $[18,19]$.

In addition to triggering changes in social and cultural structures, migrations can be effective in creating new relationships between migrated and host countries generating fundamental changes in social structures of people on both sides. If it is managed well, it can increase diversity in communities. However, as claimed by Bertolini, "migrations between regions that have different traditions and cultures are primary reasons for social disharmony" [20].

Refusal of refugees into a country has recently been observed to cause significant social wounds. Disengagement from families, statues in their home country, social values and refusals have brought along a lot of problems that have 
aggregated the feelings of being isolated and being torn apart [21]. This, in turn, often times has induced social and emotional polarization in regions where refugees live. Refugees have not been able to meet their needs and encountered many problems on account of social injustices [22,23].

One of these injustices is widely observed in the field of education specifically in cases when schools fail to become socially just learning communities that are culturally responsive to the unique needs of children from diverse backgrounds [24].

Migration causes problems in families' social life and in education specifically in primary school level, which influences both refugees and local residents. With migration, the number of students enrolled at schools increase, resources (class materials, play grounds at school, school personnel and assistant staff) become more limited, more student-related in class problems emerge, in-class democracy cannot be run and increases in discipline problems are observed [25]. Communication is another area where the negative effect of migration on education is more apparent. Future expectations of children who cannot use the host language appropriately, who cannot express himself or herself, and who cannot understand what $\mathrm{s} /$ he reads become more limited.

\section{Background on Refugees in Turkey}

Political events, coup d'états, and wars in Middle-East countries force tens of thousands people to flee their countries every year. Turkey undoubtedly holds a significant place as a host and transit country in the context of these departures. As a result of the events and civil conflicts that broke out in March 2011 in Syria, a significant proportion of Syrians who fled their countries due to civil war and conflicts have migrated to Turkey. This migration can be classified as an external and forced migration.

IHH Syrian report suggests that, by November 2012, 970 people were tortured, 47.000 people 2.148 of which were children were killed in Syria [26]. Also, 400.000 people are reported to have been arrested, 600.000 have been forced to flee to neighbor countries such as Lebanon, Jordan, Iraq and Turkey, 2,5 million people have relocated inside the country, 1,5 million people have lived at poverty threshold and 100.000 people have disappeared [26]. As of 2016, the number of registered Syrian refugees in Turkey has reached 3.1 million [27]. A 2015 report by UNICEF [28] shows details of Syrian refugees in Turkey on Table 1.

These figures must have increased by now. Given that, Turkey, among the primary host countries for refugees, have taken some measures so education process does not come a halt for children of migrated families. There are alternative practices for Syrian students in Turkey. Portative container schools are built, some public schools start to operate double-shifts (some students start early morning and leave at noon while others start at noon and finish the school in the evening) to make sure Syrian students can attend, and these students were provided with the opportunities to be taught in the same classes with their Turkish counterparts.

\section{Access to Turkish Schools}

Based on UNHCR [29], National Ministry of Education Memorandum published on September 2014 proclaims that foreign children under "temporary protection" can have access to primary and secondary schools or temporary education institutions in all cities of Turkey. These students could apply Provincial National Directorate of Education institutions and Provincial Education Councils are responsible for specifying the schools and classes these students can attend. Grade level of each student is determined by the document that shows students' grade level and in cases the document is unavailable, they take an interview or a short written assessment, and are finally places in a class. Temporary education institutions are schools built for Syrian refugees at camps or city centers and revised Syrian curriculum is taught in Arabic at these schools. These institutions are not available at all cities and do not have the capacity for all refugee children. In such cases, it is advised that families enroll their children in national school systems.

As the figure 1 shows, refugee students in Turkey can access to education services in three ways: a) in institutions inside the refugee camps, b) at temporary education centers or public schools, c) at private education institutions. Based on the information by UNHCR, temporary education centers are schools built inside the camps or at residential areas, they follow a revised Syrian curriculum, and Arabic is the language of instruction. It is unlikely to see these centers outside of camps in small cities because they are available only in 19 cities with a high population of Syrian refugees [30].

Table 1. Syrian refugees located in Turkey (retrieved from www.unicef.org.tr)

\begin{tabular}{|c|c|c|c|c|c|}
\hline $\begin{array}{c}\text { Total registered } \\
\text { Syrian refugees in } \\
\text { Turkey }\end{array}$ & $\begin{array}{c}\text { The number of } \\
\text { Syrian refugees in } \\
\text { camps }\end{array}$ & $\begin{array}{c}\text { Number of Syrian } \\
\text { refugees out of } \\
\text { camps }\end{array}$ & $\begin{array}{c}\text { Number of Syrian } \\
\text { refugee children (54 \% of } \\
\text { total number) }\end{array}$ & $\begin{array}{c}\text { Number of Syrian } \\
\text { refugee children at } \\
\text { school age }\end{array}$ & $\begin{array}{c}\text { Number of Syrian } \\
\text { refugee children not } \\
\text { attending schools }\end{array}$ \\
\hline $1,938,999$ & 259,523 & $1,679,476$ & $1,050,000$ & 606,000 \\
\hline
\end{tabular}




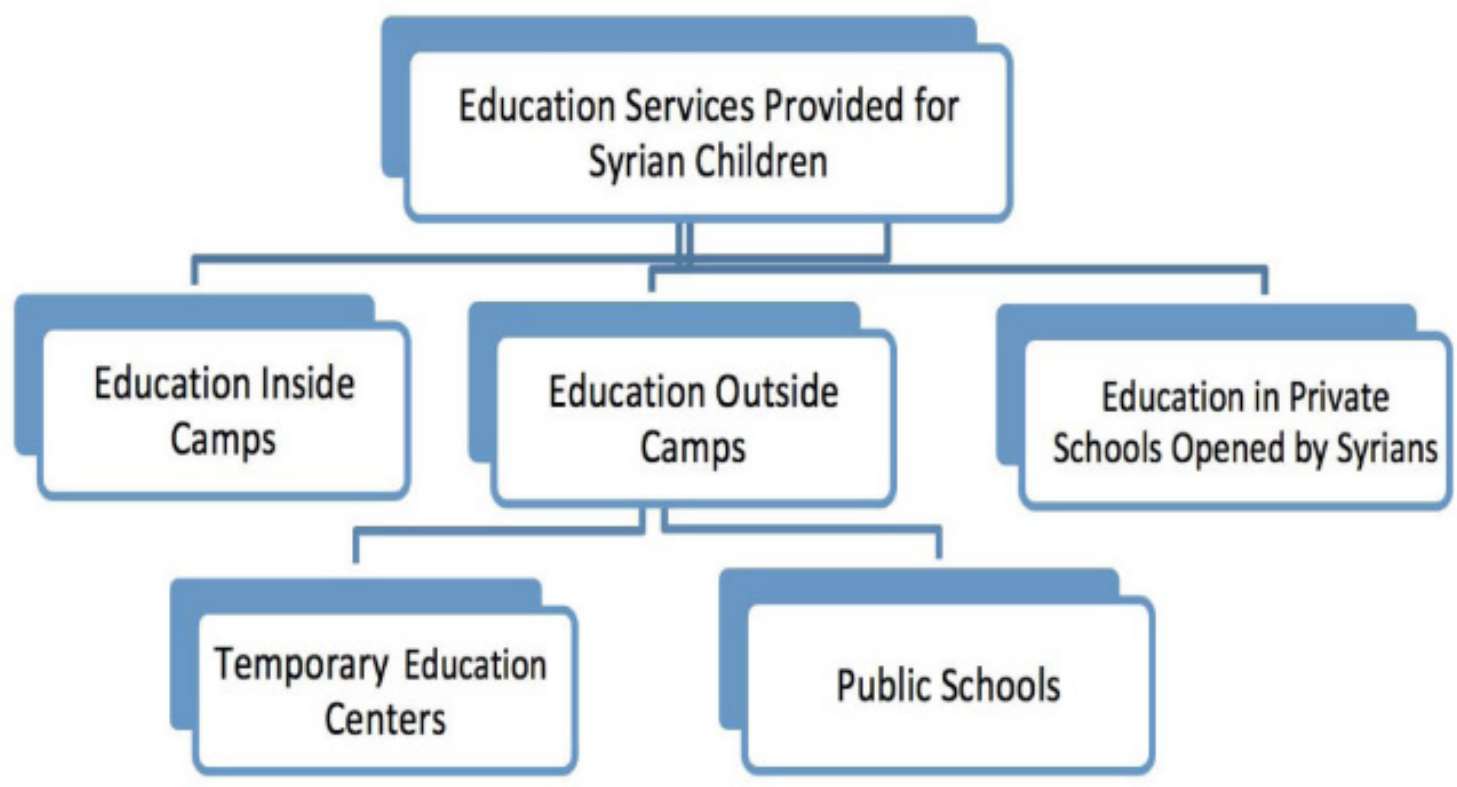

Figure 1. Education services Turkey provides to Syrian children [30].

Enrollment process for refugee children is run by a council consisting of a vice-director responsible for education and teaching, one school principal at each school level and type, one security personnel from Foreigners' Office, and one foreign language teacher or interpreter who can translate conversations during interviews. In order to be able to enroll in these schools, families need to have minimum 6-month resident permits [31].

It could be claimed that Syrian children have been granted opportunities to attend the same schools with Turkish students. However, there is not a single study that examines how these students do at school with Turkish students, how they progress academically and socially, and how they deal with communication and language problems. This study, therefore, is an attempt to shed light on the educational situation of Syrian refugee students who attend the same school with Turkish students. Based on this goal, it tries to answer the following questions:

a) Do Syrian refugee students face problems at school or in class? What are these problems if they do?

b) What is the readiness level of these students?

c) Are teachers prepared for refugee students' situation?

d) What are Turkish families' reactions?

e) How are these students' performances assessed?

f) What will they do after they graduate?

g) What can be done to provide better educational services to refugee students?

\section{Method}

\subsection{Research Design}

As the current research aims to depict personal experiences and provide a description or interpretation of the meanings of phenomena experienced by participants which is also one of the aims of descriptive phenomenological research [30], it follows a descriptive phenomenological research design that aims to "illuminate the specific, to identify phenomena through how they are perceived by the actors in a situation" [32].

\subsection{Participants}

28 teachers who were selected through criterion sampling are participants of the study. Criterion sampling strategy is used to "identify and select all cases that meet some predetermined criterion of importance" [33]. The criterion in our case is having at least one Syrian refugee student in class where the teacher participants teach. Table 2 shows more detailed information on participants of the research. Participants are coded with letter ' $K$ '.

\subsection{Data Collection and Analysis}

A semi-structured interview protocol consisting of 12 questions was used as data collection tool. Selected teachers were met individually at school settings. Collected data was analyzed by using content-analysis technique. Qualitative content analysis goes beyond merely counting words to examining language intensely for the purpose of classifying large amounts of text into an efficient number of categories that represent similar meanings [34]. Involvement of more than one researcher in the study contributes to a more transparent expression of research process, and protection of raw data. Various researchers also confirmed the data, which also has increased the trustworthiness of this qualitative study [35]. Consulting expert field opinions during preparation of data collection tools and direct quotations from participants while discussing the themes are also believed to increase validity of the research 
Table 2. Demographic Information of participants and coding

\begin{tabular}{|c|c|c|c|c|}
\hline Codes & Gender & Profession & Tenure & School Level \\
\hline $\mathrm{K} 1$ & Female & Teacher & 14 & Primary \\
\hline $\mathrm{K} 2$ & Male & Teacher & 19 & Primary \\
\hline $\mathrm{K} 3$ & Female & Teacher & 12 & Primary \\
\hline K4 & Female & Teacher & 25 & Primary \\
\hline K5 & Male & Teacher & 16 & Primary \\
\hline K6 & Male & Teacher & 20 & Primary \\
\hline K7 & Male & Teacher & 15 & Primary \\
\hline $\mathrm{K} 8$ & Male & Teacher & 11 & Primary \\
\hline K9 & Male & Teacher & 10 & Primary \\
\hline $\mathrm{K} 10$ & Female & Teacher & 2 & Primary \\
\hline K11 & Female & Teacher & 8 & Primary \\
\hline K12 & Male & Teacher & 15 & Primary \\
\hline K13 & Male & Teacher & 10 & Primary \\
\hline K14 & Male & Teacher & 10 & Primary \\
\hline K15 & Female & Teacher & 5 & Primary \\
\hline K16 & Male & Teacher & 20 & Primary \\
\hline K17 & Female & Teacher & 10 & Primary \\
\hline K18 & Male & Teacher & 13 & Primary \\
\hline K19 & Female & Teacher & 19 & Primary \\
\hline $\mathrm{K} 20$ & Male & Teacher & - & Primary \\
\hline $\mathrm{K} 21$ & Female & Teacher & 12 & Primary \\
\hline K22 & Female & Teacher & 10 & Primary \\
\hline $\mathrm{K} 23$ & Male & Teacher & - & Primary \\
\hline $\mathrm{K} 24$ & Male & Teacher & 9 & Primary \\
\hline K25 & Male & Teacher & 9 & Primary \\
\hline $\mathrm{K} 26$ & Male & Teacher & 20 & Primary \\
\hline K27 & Male & Teacher & 13 & Primary \\
\hline K28 & Male & Teacher & 20 & Primary \\
\hline
\end{tabular}

\section{Findings}

Themes identified based on data of interview with teachers are discussed below.

\subsection{In/Outside the Class Problems}

14 teachers noted that they did not face any problem with refugee students in class while 5 teachers indicated they encountered some problems in the beginning but that students overcame these problems at later stages by adapting to the class. For instance, K15 expressed: "they had problems due to language differences in the beginning. They got used to each other in time. We got over the communication problems in time". K10 also pointed out that there was not any conflict between Syrian and Turkish students and they even helped each other during games.

While 13 participant teachers expressed that they did not observe any Syrian student experiencing outside the class adaptation problems, 15 teachers highlighted the problems Syrian refugee students faced outside the class. Both participant teachers K12 and K23's statements show that Syrian students were generally grouped with other Syrian students instead of socializing with Turkish students. Some teachers such as $\mathrm{K} 2, \mathrm{~K} 8$ and $\mathrm{K} 16$ even emphasized the violent acts displayed by refugee students resulted from either groupings or language problems. Some were observed to be inclined to use violence towards their peers even involved in fights. Participant teacher K23 also mentioned refugee students' adaptation problems manifested in participation in group games on account of cultural and language-related problems.

Being able to speak Turkish, on the other hand, is articulated as a factor facilitating refugee students' adaptation both in and outside the class. Participant teacher K5 explained that because Syrian refugee students in her class could speak Turkish, they were easily bonded with Turkish students both in and outside the class. Participant 
teacher K11 articulated that problems Syrian refugee students faced were no different than problems typical Turkish students faced and that their efforts to be part of the class helped them tackle the social problems.

\subsection{Language-Related Communication Problems}

16 participant teachers expressed that they did not have any language problems while 12 of them pointed out language-based communication problems. Three of these teachers emphasized that problems are alleviated in time. However, some teachers such as K2, K16, K14 highlighted the persistence of language problems and stated that despite their efforts to solve language problems, students could not understand most of what is being communicated in class. Participant teacher 14 expressed that especially he had difficulty in explaining problems that have more than two operations or those that have technicalities, that refugee students could not fully comprehend him and that though they most of the time seemed to understand, they failed to comprehend the rationale behind mathematical operations and could not express their opinions at a comprehensible level. So, despite understanding basic instructions, Syrian refugee students have serious problems in fully following class sessions.

On the other hand, it seems that some teachers are lucky to have students who already have command in Turkish at a good level. These students are Turkmen students who use Turkish at home. For example, participant teachers K23 and K4 explained that her refugee students could speak Turkish and in cases when language creates a barrier, he got assistance from his students who are bilingual in Turkish and Arabic. Participant teacher K3 noted that while there were communication problems, these problems are not too serious to interfere with education process.

\subsection{Preparation for School and Logistics}

15 teachers who reported that refugee students generally come to class prepared also indicated that these students were not different from their Turkish counterparts in terms of preparedness. Participant teacher K1 who had two refugee teachers specified that she did not have problem in terms of cleanliness and provision of educational materials. While also indicating no cleanliness related problems, participant teacher $\mathrm{K} 1$, on the other hand, focused on educational material problems and explained that they overcame this problem with the help of supplies provided by the government. Emphasizing staggering economic conditions of refugee students, participant teacher K12 stated that they tried to solve material-related problems in cooperation with students' families as much as they could. Participant teacher K13 mentioned refugee families' mindfulness to cleanliness and nutrition, and added that educational materials were provided by the school administration.

11 participant teachers who expressed that Syrian refugee students were not prepared for class, emphasized migration-induced economic problems and families' indifference. Participant teachers K2, K22, K26 pointed out to hygiene, clothes and educational materials problems and that most students were expecting that these needs would be met by the Turkish government. In fact, teachers explained that some families do not meet these needs based on their expectations from the government.

\subsection{Readiness and Success}

16 teachers indicated that Syrian refugee students' readiness is at normal level while 12 teachers complained about their readiness level and that families did not take care of their children' success at school. Teachers who are positive about their readiness level emphasized these students' success specifically in courses like maths and music. Both participant teachers K1 and K10 pointed out their students were very engaged in all courses, emphasized their success specifically in maths classes and $\mathrm{K} 1$ also added that his students were very careful about doing their assignments completely. Participant teachers K4, K5 and K17 articulated that these students' success levels are above Turkish students. In general, more than half of teachers noted that Syrian refugee students were as successful as Turkish ones with their own efforts.

12 teachers, on the other hand, mentioned lack of readiness level and emphasized Syrian refugee students' lower success level than that of Turkish students. Participant teacher K2, in addition to low readiness level, attributed lack of success to language problems. Participant teacher K16 saw the breaks they had from regular classes as reasons for the academic problems students had and stated that these problems are more evident in Turkish and Maths classes. However, while participant teachers K18 and K22 talked about students' success in Maths classes, they also mentioned more observable failures in verbal courses. While observing negligible academic success problems, participant teacher K23, however, emphasized their failure to adapt to Turkish national values

\subsection{Teachers' Participation in Decision-Making}

21 of participant teachers stated that their opinions were not sought and they were not involved in allocation process of students to classes. 7 teachers expressed that they were only informed about the fact that certain Syrian students would come to their classes without asking for any opinions about how the process should be run and what should be made. Participant teachers K16, K13 and K25 said that Syrian students who came to their schools were equally distributed to classes without any previously set criteria.

Teachers whose opinions were not asked while students were sent to their classes complained that the process took place in a haphazard fashion. They emphasized that the process should have been thoroughly discussed and they 
should have been adequately informed about the process. One participant teacher (K1) even expressed that he developed some biases towards Syrian students due to the lack of their involvement process and lack of information. In addition, participant teacher $\mathrm{K} 2$ stated that he suddenly became teacher of these "alien" students without knowing what to do. Lack of information was so serious that participant teacher K27 even noted he just learnt about those students by seeing their names on the list without getting any bit of information. What is worse, when he went to talk to school administration, they expressed that they had not been informed about these students, either, that it was surprising and instant for them to, thus, they did not have any information to give to teachers.

11 teachers indicated that they generally did not face any problem with these students and when they faced a problem, they tried to solve it by themselves. 4 teachers (K11, K2, K15, K16, K18) pointed out teachers' need for professional development. Participant teacher K15 thought things would have been easier for him if he could speak Arabic while participant teachers K23 thought teachers who could speak Arabic should have been assigned to Syrian students. Participant teacher K16's point that they did not have any experience with foreign students and that this created a huge disadvantage for him is an important point to be considered. $\mathrm{K} 18$, on the other hand, emphasized lack of infrastructure and capacity of schools, and stated that giving education in such harsh conditions led to various negative outcomes.

\subsection{Performance Assessment Process}

24 teachers stated that assessment process for refugee students was made properly while only 3 teachers expressed concerns about assessment. 4 teachers who expressed that no problem was faced in assessing refugee students' performances also indicated that they took affirmative actions in favor of Syrian refugee students by considering disadvantages these students had.

25 students noted that they got positive results from assessments. Participant teacher K3 articulated that he did not discriminate between Syrian and Turkish students in assessment and that Syrian students received higher grades. Participant teacher K17 also stated that he assessed Syrian students' performance the same way as he followed for Turkish students and that Syrian students were equally successful in the tests. Another teacher who used the same assessment procedure for Syrian students mentioned that while Syrian students were found to be less successful in verbal lessons, they achieved similarly in maths, arts and music courses.

Participant teacher K2, however, stated though he used the same tests to assess Syrian students' performances, Syrian students achieved worse than others. Participant teachers K13 emphasized that gains from pivot courses were not suitable for Syrian students' levels. Therefore, these courses seem to be evaluated more superficially by teachers.
Moreover, since teachers know that these students have not fully grasped the content, there appears to be a tendency to use different ways for assessment.

Additionally, while a total of 19 teachers used the same assessment process for Syrian and Turkish students, 6 teachers confessed that they took Syrian refugee students' in-class performance into account in addition to the grades they got formal tests.

\subsection{Turkish Parents' Reactions}

It was reported that based on 17 teachers' statements, parents were neutral in their reactions towards presence of refugee students in their children' class, 9 teachers believed that parents were quite reactive towards these students while only 2 teachers thought parents were tolerant towards them.

Participant teacher K13 stated that parents were complaining due to overcrowded classes and believed that Turkish students should be given the same care by authorities. That can further be explained that some parents think that Turkish students are seen as less valued by the authorities in comparison with Syrian students. Participant teacher K24 stated that Turkish parents were more concerned about hygiene problems and were anxious that their children would suffer from this.

Participant teachers K15 and K21 who thought Turkish parents gave positive reactions stated that the parents gradually come to accept this situation and become tolerant towards refugee students in class.

\subsection{Steps to Increase Effective Learning}

5 teachers reported that Syrian refugee students must be given opportunities to get education in their mother tongues in line with their own cultures while 6 teachers believe that is better for them to follow the same program with Turkish students. 9 teachers emphasized that with increased families' engagement, refugee students could be better adapted to Turkish educational system and culture which will, in turn, make up for shortcomings in education process. 12 teachers mentioned measures to be taken so both students and parents can learn Turkish at a better level.

As stated by participant teacher K28, if refugee students are given chances of getting education in their own languages, they will become more successful learners. Participant teachers K26 and K27, language problems must be handled first so refugee students could be better prepared for classes and once their reading, comprehension and speaking problems are solved, they will be more engaged learners. Participant teachers K5, K1, K20 emphasized that refugee students' presence in the class could help overcome language problems more easily. They stated that placement of refugee students in different classes could bring about feelings of social exclusion and timidity; thus, their active involvement in the school and wider community will increase their academic achievement and social harmony. 
Participant teachers K2, K8 and K24, on the other hand, believe that refugee students should go to different schools built specifically for them, they should go to schools where they can learn in their own languages, and where refugee teachers follow a curriculum that is tailored to meet their needs.

\subsection{What Happened after Graduation}

15 teachers were positive about refugee students' future stated that refugee students will graduate the same way with Turkish students while 10 more pessimistic teachers noted that they cannot graduate from Turkish educational institutions like Turkish students and they will in a more disadvantaged position.

Participant teachers such as $\mathrm{K} 1, \mathrm{~K} 23$ and $\mathrm{K} 15$ who is one of the more optimistic teachers pointed out that refugee students were bilingual (Arabic and Turkish) and in case they continue to study in Turkish schools and are given academic support they will be in an advantaged position as opposed to their Turkish counterparts. Participant teachers K11 stated the longer they stayed in Turkey, the more successful they would be. Conversely, participant teacher K14 the problems (social, academic etc.) that have been facing put refugee students in a disadvantage position and participant teacher K12 mentioned that without extra help refugee students would fall behind their Turkish peers and would face hardships finding employment after graduation. Participant teachers K22 and K26 highlighted the already increased rate of unemployment in Turkey and stated the refugee students would create and extra burden and it would be unlikely to find jobs easily. Focusing on the language problems, participant teacher $\mathrm{K} 2$ also believed that refugee students' academic future would not be so bright and they would probably resort to more low-paid jobs.

\subsection{Meetings with Refugee Parents and Their Expectations}

20 teachers stated that they come together with refugee parents from time to time. However, 8 teachers have confessed they had never met refugee students' parents. 16 teachers expressed their expectations from parents while 10 noted they had no expectations from parents.

Participant teacher K1 expressed that refugee parents participated in field trips and presentations when they are invited and he expected more parents' support during class activities aimed at refugee students. Participant teacher K8 also expressed that refugee parents actively participate in parents' meetings and he asked them to be considerate due to differences in language and culture. In contrast, participant teacher K2 said that due to language problems refugee parents tend not to participate in parents' meetings.

\subsection{What to Do Next}

While 8 teachers expressed that they are happy with refugee students' performances, 10 teachers indicated their dissatisfaction with them emphasizing that refugee students need to put in more effort in their adaptation to school, class and school environment. 12 teachers specifically pointed out language and cultural differences and suggested creation of an educational environment in line with their language and culture.

Participant teacher K14 mentioned the importance of extra activities for refugee students and their placement in a totally different school where they have a different curriculum and they can use Arabic. Some teachers such as participant teacher K23, however, believe that in order to help refugee students get rid of problems they have, it is better for them to go to Turkish schools where the rehabilitation process could be better and they can be away from violent acts. A more marginal suggestion was made by K25 who advised that refugee students should be sent back to tent camps and their inclusion to Turkish social life should be prohibited.

\section{Discussion and Conclusions}

Turkey has opened its doors to thousands of refugees who were displaced due to civil unrest that broke out in 2011. It announced a legal framework known as "temporary protection" probably with the hope that they will sooner or later return to Syria [36].

Education is an important need for the future of refugee children, and it is an influential and a vital leverage in terms of successful integration of refugee children into the host country. War traumas make asylum and refugee seeking children the most vulnerable group, and raise moral obligations of host nations to a higher order [37]. As emphasized by Pascual [38], once refugees have met their basic need for food, water and shelter, their primary concern is to ensure that their children can attend school. So, education is one of the basic and foremost needs of refugee children. Thus, international and local education and social policies need to be readjusted to address this basic human right.

It must be noted that while many of these refugees have been given shelter in tent camps in cities such as Gaziantep, Kilis, Şanlıurfa, a great number of them now reside in city centers in Turkey. First, it is upsetting that, based on teachers' observations, many displaced refugees who had witnessed or experienced violent acts, death of a parent or relatives, still suffer from various psychological distress such as post-traumatic stress disorders. There is well-documented research showing that dislocated refugee children who were exposed to war-related violence suffer from various psychological distresses which can also lead to mental health problems [39]; [40]; [41]; [42]; [43]. Psychological wellbeing of immigrant students is affected by how well the schools and local communities in their country of destination help them to overcome the myriad obstacles they face in succeeding at school and building a new life [44].

A more recent study shows that a great majority of Syrian 
refugee children have experienced traumatic events that lead to post-traumatic stress disorders, depression and psychosomatic problems [45]. Lack of any systematic program to detect these psychological problems, and to rehabilitate these children seem to make the situation worse for refugee students who were randomly placed at Turkish schools without documenting psychological problems and without using documented information for the well-being of children. It would be logical to say in these circumstances that these students must feel "lost in the desert" without speaking the language while simultaneously suffering from the effects of psychological problems they have brought with them. As emphasized by Ramsten and Spoonley [46], students need to feel culturally safe at schools and for this all individuals need to be open and flexible in their attitudes towards people from different cultures to whom they deliver service, refugee students should be given an environment where they do not feel disempowered and demeaned by the actions and delivery systems of other people. Though refugee students are less in number within the host country students, incorporating their cultural elements could contribute to their integration. Thus, teachers should strive for creating a multicultural classroom environment where diverse cultures are valued and individuals from different cultural backgrounds are equally empowered.

Turkish political administration has exerted efforts to accommodate these children by placing them in educational institutions and supporting them financially. However, as shown by this study, these efforts were made in a haphazard manner lacking any stable system that considers the possible psychological, language-related and cultural problems these refugee children face. These efforts deserve appreciation because these are series of steps taken to prevent refugee children who suffer from a possible continual deprivation from education and are efforts to increase access to education. However, the problem facing Syrian refugee children in Turkey is not a matter of access but a matter of quality. As stated by Bourgonje [37], in many cases little attention is still being paid and little efforts are made in teacher education programs to equip teachers with skills to teach in the multicultural and multilingual classroom. Also, the lack of support and programs at the school level in terms of better dealing with refugee children are observable. Turkish schools tend to welcome refugee children and school administrations seem to be ready to provide education materials for these children. Nonetheless, the questions of what background these children have, how they are affected by their previous experiences, whether they can get much of the content presented to them or not seem to go unnoticed by school administrations and policy makers at higher level. After all, the idea behind humanitarian aid is to ensure continued access to quality public education, in a safe and protective environment, for all vulnerable children [47]. Achievement of such a goal within the framework of Turkey's provisions to migrant children sadly looks far from reality.
It should also be noted, as evidenced by teachers' experiences, that language has always been a major obstacle beyond refugee students' access to quality education. As expressed by many teachers, refugee students who were not given any formal training on learning Turkish struggle at Turkish schools as they do not seem to comprehend most of the content given in class, and have serious problems in expressing themselves. These problems, that have the potential to be aggregated into social problems, cause refugee students to be grouped with other refugee students instead of socializing with others. This finding is in line with Şeker and Sirkeci [48] who also found out that refugee children's problems mainly stem from language barriers and cultural differences. Though teachers are generally aware of the language problems, they feel hopeless, as they are not given resources or opportunities to meet these needs. There does not seem to be any apparent capacity building effort within Turkish education system to meet these needs of teachers. As also found out by Jones, Buzick, and Turkan [49], there seems to be little concern about whether refugee students' language learning needs are met.

Similarly, UNHCR's report [50], on refugee children in Lebanon mentions language barriers "a cross cutting issue that hold students back on all levels of learning". UNICEF [46] sees language barriers as one of the top reasons behind children' dropping out. Therefore, policies on aiding refugee children so they can better benefit from education services should capitalize on language barriers together with psychosocial problems.

The lack of a system or program to help these children become proficient in Turkish language cause both academic and social problems as not being able to fully comprehend classes, probably after several efforts, they tend to become less engaged and learn less at school. This lack of achievement appears to be more evident especially in verbal lessons such as history, geography, and social sciences as they seem to do better in maths and sciences despite language problems. One main reason behind this could be that mathematics has a universal language and mostly consists of symbols [51,52]. So, the need for learning the language of host country is a pressing issue.

With distribution of refugee students into already crowded classes, classes become overcrowded and some Turkish parents overtly complain about this. Not surprisingly, limited instructional time and crowded classes affect educational quality, thus, there is a felt need for more monitoring, training and support at organizational and individual level [55]. Placement of refugee students in class seems to have aggregated the problem of overcrowded classes. Similar problems exit in Jordan as public schools are already crowded and additional refugee students make the situation worse which also forces schools operate on double shifts [52]. While most Turkish parents seem to approach presence of refugee students positively, some are concerned about the overcrowded classes, hygiene problems and they are even anxious that their children will catch some diseases allegedly 
carried by refugee students. Some Turkish families even come to believe that their own children are seen less-valued by school administration emphasizing that a lot of resources and attention are allocated to refugee children. Similar problems are documented in Jordan $[53,54]$.

One of the most striking finding is that Turkish teachers are not made a part of decision-making regarding refugee children, are not informed about the background of the students who are placed in their classes, and worst of all, they just happen to learn that refugee students are placed in her/his class upon arrival at class by looking at the new class rooster. Not being informed about any process of refugee students' allocation and being deprived of information seem to frustrate teachers as they believe they should have more autonomy in decision-making and allocation of students. They also believe their voices regarding a better education for refugee children must be heard. Therefore, poor management practices appear to be the focal point for problems refugee children face. Given this, Brown's [56] call for fostering cooperation and motivation among all actors involved and ensuring that appropriate training is given to managers and teachers is better understood.

Though most teachers seem to follow the same assessment procedures during performance assessment of refugee students, there seem to be certain cases in which teachers feel the need to take in-class performances of these students, a procedure that is not followed for their Turkish peers. Teachers justify this by emphasizing that refugee students generally have low achievement levels in pivot classes caused by language problems and they tend to fill this achievement gap by using in-class performance indicators in favor of refugee students. This is an interesting finding and there is not much of documented research about favoring refugee students during assessment procedures. Therefore, there is need for further research on that field.

Another matter that should be considered is about refugee students' future and their employment opportunities in Turkey. Based on an OECD report [57], one in five economically active refugees is unemployed and refugees seem unlikely to compete with native-born citizens. However, it must be stated that in Turkey's case, being bilingual in both Arabic and Turkish is seen a strong advantage of refugee students. Still, the psychological distresses they have gone through, financial problems, adaptation problems they encountered when they first immersed into a new community with a different language and culture and ensuing difficulties at school that are reflected on their achievement level are seen by teachers as factors that put them into a disadvantageous situation. Also, already boomed rates of unemployment seem to deteriorate the chances of employment for Syrian refugee students who live in a country where financial situation seem to deteriorate in last two or three years.

There is the debate of whether refugee students should be taught at schools specifically designed for refugee students, that follows a curriculum tailored for refugee students' needs and where only teachers who speak Arabic work or whether they should be immersed into Turkish schools. There are teachers at both sides in the current study. There are arguments that support establishment of separate schools with curriculum tailored for refugee students, and these arguments are justified such that such schools will better address these students' needs, students will not miss content and encounter communication breakdowns due to language problems, and they will not be put in a disadvantaged situation because the education environment at their home countries will have been moved to another country without any change. Research shows that students who attend schools where the concentration of immigrants is high (i.e. where more than one in four students are immigrants) tend to do worse in school than students who attend schools where there are no immigrant students [43]. So, creating small group of refugee students and placing them in various schools instead of creating a high concentration of refugee students in one class or school will be a better strategy in terms of integration and inclusion of them in the host country. That way, students can be better catered and their groupings and shying away from socializing with other students could be prevented.

Education institutions are tools for policy makers both to give refugee students a sense of welcome and to integrate them to the host country. In that sense, education institutions can substantively contribute to the successful resettlement of refugee children, and in order for these students to become integrated culturally, socially and economically, they should be provided with intensive language and learning support, which can be achieved by incorporating refugee children into mainstream classrooms [58]. Otherwise, not involving them in mainstream education process will create islands of loneliness, disintegration, fear and the idea of "them versus us" which could further feed feelings of hatred, violence, discrimination, and hopelessness. As emphasized by Kirişçi [36], a school curriculum in Turkish, or at least a program with a strong element of Turkish, will be critical to the functioning of these children in Turkish society as adults. Therefore, policy makers should work more on more inclusive practices to make refugee students a part of their new community.

Given the problems that refugee students who attend Turkish schools have been facing, two serious problems that necessitate urgent care emerge: a) refugee students who do not speak Turkish face a lot of challenges at Turkish schools as they do not comprehend much of classroom talk and the inability to express themselves decrease their engagement, $b$ ) teachers are perceived as passive recipients during the process of distributing students to classes, they are not given adequate information about students who are placed in their classes, and they are not given opportunities to develop their potential to better deal with refugee children, c) parents who do not speak Turkish refrain from being involved in their children's education. The heart of education lies with the teachers, and refugees require caring, nurturing teachers who 
understand their unique needs, who are willing to make the relationships necessary to help them grow, and who have the support staff to ensure that these needs are met [59]. However, providing access to refugee children seem to operate as the sole goal of the authorities within the context of refugee students in Turkey, and there does not seem to be an affective system that will render professional development programs to teachers who are hardly informed about the concept of "forced migration", that will prioritize learning Turkish language, and that will better accommodate refugee children and help them ease their adaptation by providing more rigorous psychological counseling services. Education For All (EFA) lists six goals of refugee education: free access to primary education, equitable access to appropriate learning for youth and adults, increasing adult literacy, eliminating gender disparities and quality education [60]. Therefore, focusing on only one goal set for refugee education will not solve the problems and it can even further complicate the problems. Throwing refugee students at an unknown sea and asking them to swim to survive will not make refugee students part of a "hospitable" society, nor will it help these students heal their wounds and become better achievers at school and in the wider society.

\section{Policy Suggestions}

Policy makers should put more emphasis on language and learning support for refugee students. For this, students could be provided with an intensive Turkish language learning package prior to their placement at Turkish schools. Though the Turkish government has named the refugee services under the name of "temporary protection" emphasizing that they will be repatriated to their home country, it seems the civil war in Syria will continue for some more time and these children could grow up in this country even after the war ends. Therefore, fully integrating refugee students in Turkish culture and education system should be a more prioritized goal for Turkey.

A minimum 1-month language learning process could help students understand the content at schools and follow classes more effectively. Since they will be immersed in the host culture, this formal language learning will set a stepping stone for them, they will learn Turkish faster because living in a country and being exposed to continuous language input will help them have a good command on Turkish. Other interventions that could help students recover from psychological problems, and trauma could also be initiated with the help of professionals who could cooperate with teachers, school counselors and school administrators. Various opportunities can be given to teachers to learn about working with refugee students and to build the skills necessary to help students succeed at schools and in the community. Teachers should be culturally sensitive and refrain from actions that could isolate refugee students. These trainings need to focus on the lives and cultures of the refugees, as well as the traumatic and violent histories these students bring with them. Capacity and potential of teachers of these students should also be developed through various intervention programs that include refugee related concepts, processes, history of this refugee crisis. This study also shows the need for further research that could provide more evidence about refugee students in the same host country schools with the same curriculum versus separate schools or curriculums.

\section{REFERENCES}

[1] Akkayan, T. (1979). Göç ve değişme. [Migration and change]. İstanbul: Edebiyat Fakültesi Basımevi.

[2] Hoşgör, Ş. (1998).Türkiye'de kantitatif yöntemlerle dolaylı göç tahminleri: Sorunlar ve yaklaşımlar.Türkiye'de İç göç. [Migration predictions based on quantitative methods in Turkey: Problems and approaches, internal migration in Turkey]. Türkiye Ekonomik ve Toplumsal Tarih Vakfı Yayınları, İstanbul.

[3] Bhugra, D. \& Gupta, S. (2011). Introduction: Setting the scene. In Bhugra, D., \& Gupta, S.(Eds.), Migration and mental health (pp. 1-15). UK: Cambridge University Press.

[4] Gün, Z., \& Bayraktar, F. (2008). Türkiye'de iç göçün ergenlerin uyumundaki rolü [The role of internal migration on adolescents' adaptation]. Türk Psikiyatri Dergisi, 19(2), $167-176$

[5] International Organization for Migration (2011). Key migration terms. Retrieved from http://www.iom.int.

[6] Türk Dil Kurumu (TDK) (2011). Türkçe Sözlük [Turkish dictionary].Ankara: TDK Yayınları.

[7] Yalçın, C. (2004). Göç sosyolojisi [Migration sociology]. Ankara: Anı Yayıncilik.

[8] Tümertekin, E., \& Özgüç, N. (1998). Beşeri coğrafya. [Human geography]. İstanbul: Çantay Kitabevi.

[9] Tanfer, K. (1983). Internal migration in Turkey: Socioeconomic characteristics by destination and type of move. Studies In Comparative International Development, 18(4), 76- 111.

[10] Abadan-Unat, N. (2002). Bitmeyen göç [Unending migration]. İstanbul: İstanbul Bilgi Üniversitesi Yayınları

[11] Tomsa, R. (2010). Psychological consequences of temporary labor migration upon children and family. Petroleum-Gas University of Ploiesti Bulletin, Educational Sciences Series, 62(2), 206-212.

[12] Tekeli, İ. (1998).Türkiye'de iç göç sorunsalı yeniden tanımlanma aşamasına geldi [Internal migration problem has come to a redefinition phase in Turkey]. .Istanbul:Türkiye'de İçgöç,Türkiye Ekonomik ve Toplumsal Tarih Vakfi Yayınları.

[13] Özer, İ. (2004).Kentleşme, kentlileşme ve kentsel değişim [Urbanization, urbanizing and urban change]. Bursa: Ekin Kitabevi. 
[14] Özkalp, E. (1990). Sosyolojiye giriş. [Introduction to sociology].Eskişehir: Anadolu Üniversitesi Yayınları.

[15] Erkan, R., \& Bağlı, M. (2005). Göç ve yoksulluk alanlarında kentle bütünleşme eğilimi: Diyarbakır örneği [Trends of integration with cities during migration and poverty: Sample of Diyarbakir]. Hacettepe Üniversitesi Edebiyat Fakültesi Dergisi, 22(1), 105-124.

[16] Wood, W. B. (1994). Forced migration: Local conflicts and international dilemmas. Annals of Association of American Geographers, 84(4),607-634.

[17] Ünalan, T. (2006). Ülke içinde yerinden edilme konusunda dünyada durum ve eğilimler. In Kurban, D. Yükseker, D., Çelik, A.B., Ünalan, T. Aker, A. T. (Eds.). Zorunlu göç ile yüzleşmek: Türkiye'de yerinden edilme sonrası vatandaşlı̆ıın inşası, (pp.29-38), Istanbul: TESEV Yayınları.

[18] Fichter, J. (1990). Sosyoloji Nedir?.Çev. Nilgün Çelebi, Istanbul: Selçuk Üniversitesi Yayınları.

[19] Aslan, C. (2001). Göç- eğitim- Batman ve çocuk: Doğu ve Güneydoğu Anadolu'da göçün aile ve çocuk eğitimi üzerindeki etkisi. [ Migration, education, Batman and children: The effect of migration in East and South East Anatolia on family and children' education]. Retrieved from http://egitim.cukurova.edu.tr

[20] Yavuzer, H. (2001). Çocuk ve Suç [Child and crime]. İstanbul: Remzi Kitabevi.

[21] Kurtuluş, H., \& Purkis, S. (2008). Türkiye'den Kuzey Kıbrıs'a göç dalgaları: Lefkoşa'nın dışlanmış göçmen-enformel emekçileri. [Migration waves from Turkey to Northern Cyprus: Isolated migrated informal laborers of Nicosia]. Toplum ve Bilim, (112), 60-101.

[22] Tellal, E. (1994). Göçmen işçiler, yaşam koşulları ve son uluslararası sözleșme [Migrated workers, life conditions and latest international contract]. Ankara Üniversitesi Siyasal Bilimler Fakültesi Dergisi, (49), 415-427.

[23] Sallan-Gül, S. (2001). Dışgöçler, yoksulluk ve Türkiye'de göçmenlere yönelik yardımlar. [External migrations, poverty and aid provided to refugees in Turkey]. TODAIE Insan Haklarl Ylllı̆̆ , (22-23), 79-93.

[24] Stewart, J. (2014). The school counsellor's role in promoting social justice for refugee and immigrant children. Canadian Journal of Counselling and Psychotherapy (Online), 48(3), 251.

[25] Karakuş, E. (2006)..Göç olgusu ve eğitime olumsuz etkileri (Sultanbeyli örneği) [Migration concept and its negative effects on education: Case of Sultanbeyli].Unpublished Master's thesis. Sakarya Üniversity Institute of Social Sciences, Sakarya.

[26] İHH (2012). Suriye raporu (Mayıs 2011- Kasım 2012). [Syria Report (May 2011-November 2012]. Retrieved from http://www.ihh.org.tr

[27] European Commission Humanitarian Office (2016).Türkiye: Mülteci krizi. Retrieved from http://ec.europa.eu.

[28] UNICEF (2015). Access to education for Syrian refugee children and youth in Jordan host communities. Retrieved from http://reliefweb.int.

[29] UNHCR (2015). Legal Framework for Syrian refugees in Turkey. Retrieved from http://unhcr.org.
[30] Coşkun, İ., Emin, M. N. (2016). Türkiye'deki Suriye’lilerin eğitiminde yol haritası firsatlar ve zorluklar. [A road map for education of Syrians in Turkey: Opportunities, challenges]. Retrieved from http://www.setav.org.

[31] MEB (2010). Yabanc1 uyruklu öğrenciler genelgesi. [Foreign students notice]. Retrieved from http://www.multeci.org.tr.

[32] Padilla-Díaz, M. (2015). Phenomenology in educational qualitative research: philosophy as science or philosophical science? Educational Excellence, 1(2), 101-110.

[33] Lester, S. (1999). An introduction to phenomenological research. Retrieved from https://www.rgs.org.

[34] Patton, MQ. (2001). Qualitative research and evaluation methods (2nd Edition). Thousand oaks, CA: Sage Publications.

[35] Weber, R. P. (1990). Basic content analysis. Beverly Hills, CA: Sage

[36] Kirişçi, K. (2014). Syrian refugees and Turkey's challenges: Going beyond hospitality. Retrieved from https://www.brookings.edu.

[37] Bourgonje, P. (2010). Education for refugee and asylum seeking children in OECD countries. Education International, $50,1-12$.

[38] Pascual, M. J. V. (2003). Key aspects about education for refugee children. Revista Española de Educación Comparada, (9), 225-260.

[39] Foster, H., \& Brooks-Gunn, J. (2015). Children's exposure to community and war violence and mental health in four African countries. Social Science \& Medicine, 146, 292-299.

[40] Freh. F.M (2015).Psychological effects of war and violence on children. Journal of Psychological Abnormalities. doi:10.4172/2329-9525.1000e001.

[41] Catani, C., Jacob, N., Schauer, E., Kohila, M., \& Neuner, F. (2008). Family violence, war, and natural disasters: A study of the effect of extreme stress on children's mental health in Sri Lanka. BMC Psychiatry, 2(8), 33, doi: $10.1186 / 1471-244 \mathrm{X}-8-33$

[42] Lustig, S. L., Kia-Keating, M., Knight, W. G., Geltman, P., Ellis, H., Kinzie, J. D., \& Saxe, G. N. (2004). Review of child and adolescent refugee mental health. Journal of the American Academy of Child \& Adolescent Psychiatry, 43(1), 24-36.

[43] Fazel, M., Reed, R. V., Panter-Brick, C., \& Stein, A. (2012). Mental health of displaced and refugee children resettled in high-income countries: risk and protective factors. The Lancet, 379 (9812), 266-282.

[44] OECD (2015). Helping immigrant students to succeed at school and beyond. Retrieved from www.oecd.org.

[45] Özer, S., Şirin, S.R., \& Oppedal, B., (2013). Bahçeşehir Study of Syrian Refugee Children in Turkey. Retrieved from https://www.fhi.no.

[46] Ramsden, I. \& Spoonley, P. (1993). The cultural safety debate in nursing education in Aotearoa. New Zealand Annual Review of Education, 3, 161-174.

[47] UNICEF (2015). Türkiye'deki Suriyeli çocuklar [Syrian refugee children in Turkey]. Retrieved fromhttp://unicef.org.tr 
[48] Şeker, B. D., \& Sirkeci, I. (2015). Challenges for refugee children at school in Eastern Turkey. Economics \& Sociology, $8(4), 122-133$.

[49] Jones, N. D., Buzick, H. M., \& Turkan, S. (2013). Including students with disabilities and English learners in measures of educator effectiveness. Educational Researcher, 42(4), 234 241.

[50] UNHCR (2014). Barriers to education for Syrian refugee children in Lebanon. Retrieved fromhttps://www.hrw.org.

[51] Hacısalihoğlu, H. H., Mirasyedioğlu, Ş., \&Akpınar, A. (2004). Ilköğretim 6-8 matematik ögretimi: Matematikte işbirliğine dayall yapılandırıcı ögrenme ve ögretme [Secondary school 6-8 maths teaching: Cooperative learning and teaching in mathematics]. Ankara: Asil Yayın Dağıtım.

[52] Ünlü, M., \& Aydıntan, S. (2011). İlköğretim 8. sınıf öğrencilerinin matematik öğretiminde öğrenci takımları başarı bölümleri tekniği hakkındaki görüşleri $\left[8^{\text {th }}\right.$ grade students' opinions on students' teams success parts method in maths teaching].11(1),101-117.

[53] HRW (2015). We are afraid for their future: Barriers to education for refugee children in Jordan. Retrieved from https://www.hrw.org.
[54] UNICEF (2015). Every child reaching their potential through learning. Retrieved from www.unicef.org.tr.

[55] Culbertson, S., \& Constant, L. (2015). Education of Syrian Refugee Children: Managing the Crisis in Turkey, Lebanon, and Jordan. Retrieved from http://www.rand.org

[56] Brown, T. (2001). Improving quality and attainment in refugee schools: The case of the Bhutanese refugees in Nepal. Education in Emergencies, 109-162.

[57] OECD (2014). How are refugees faring on the labour market in Europe? Retrieved from www.oecd.org.

[58] Taylor, S., \& Sidhu, R. K. (2012). Supporting refugee students in schools: what constitutes inclusive education? .International Journal of Inclusive Education, 16(1), 39-56.

[59] Cooper III, T. C. (2014). Refugee Students: Educational Challenges and Strategies for Leaders Working with Third World Populations. The University of North Carolina at Chapel Hill. Retrieved from https://cdr.lib.unc.edu.

[60] UNESCO (2015). Education for All movement. Retrieved from www.unesco.org. 